\title{
Waste knot, want knot
}

\author{
A trip to the shops.
}

E veryone was curious about the shops. Everyone except Jenna Sloane. Even her boyfriend, Brian, succumbed to the hype, despite her warnings. Before he got three words out, she cut him off. "Look, Brian, I'm not kidding. Drop it."

Brian scowled. "I don't like censorship," he said.

"It's not censorship," she replied, smiling. "More like a benign dictatorship."

But Brian didn't smile back. Instead he shook his head, got up and walked out of the coffee shop.

She never saw him again.

Picking out clothes for donation from her storage closet, Jenna chanced on a dusty blanket with distinctive knot patterns. A keeper, she thought, and set it aside. It reminded her of happier days.

Sorting completed, she moved on to the next Sunday evening chore, laundry. For distraction, she turned on the news. A shopcentred story came to life on the screen, and she immediately switched to a different channel. Too late. The damage to her fragile emotions had been done.

Despite herself, she still missed Brian. He had been the first she'd seen it happen to, after which she'd named it shifting. Whenever someone - famous, anonymous, it didn't matter - entered one of the new, unmarked shops, or talked directly about them, that person disappeared. And then all of reality, including everyone's memories - except Jenna's, apparently - shifted, removing all traces of that person's existence. The only way to stay safe, she had discovered, was never to speak directly about the shops and, of course, never to go anywhere near one.

Shivering, she focused back on the screen, where an interview caught her eye. Was that Jeremy Baker, former classmate, turned gamedesign entrepreneur? She'd flirted with him in high school, but he'd been overly serious, self-absorbed. Now, beamed into her house, he seemed funny and warm. And when he was coyly asked if he had any unusual places at which he liked to shop, he looked away $\rightarrow$ NATURE.COM

Follow Futures: y @NatureFutures f go.nature.com/ mtoodm from the camera and said nothing.

Hmmm, thought Jenna, wondering if she still had his e-mail address.
They hung out on social media, began texting, finally agreed to go out. Four dates and two dizzying weeks later, Jenna and Jeremy shared their first morning-after breakfast in his enormous kitchen.

"So, what made you look me up after all this time?" Jeremy asked, flashing a stubbly grin. "Was it the Forbes write-up or the New Yorker interview?"

"Oh my god," Jenna said, playfully rolling her eyes. "I thought you'd grown up."

"That sounds painful," he quipped. "I'd rather be wildly successful while keeping my child-like wonder about the world."

His joke struck a nerve. "Kidding aside," she said, "one thing did catch my attention. In interviews there's a topic you always avoid."

His face became as serious as hers. "Yeah. I don't want to become a casualty."

Jenna's eyes widened. "Jeremy, you're the first person besides me who seems to understand how it works. To remember the changes." She slapped his marble kitchen counter. "Has the whole world gone insane?"

"I learned the hard way," Jeremy said. "My parents tried to get me to go with them once. I didn't."

Loss seemed to pool in his big brown eyes, stilling Jenna. "I'm sorry," she said.

"That's when I realized I had to do something. Honestly, it's why I set up Polygnosis. We're looking into things quietly, indirectly, of course. I've hired some of the world's best minds to do oblique research."

Jenna's heart surged in her chest. Tentatively, she asked, "Have they found anything?"

"Not yet," he said. "They're working on correlations. Trying to discover the commonalities between people who remember how things used to be."

People like me, Jenna thought.

Late one night, six months later, after too much champagne, they snuggled in Jeremy's bed, drifting as newlyweds for the first time. "Perfectly closed systems," Jenna blurted out. "As though the Universe is ensuring that certain bits of information don't ever get out."
Jeremy, eyes still closed, played with her hair. Jenna drew closer to him. "Have you heard of the cosmic censorship hypothesis?" she whispered.

"Nature doesn't allow naked singularities," Jeremy said, finally opening his eyes. "You think we're dealing with black holes?"

"Nah," she said. "No gravitational disturbances. But maybe something like singularities. Something we're not supposed to see."

"Then why appear in the first place?"

"If we do live in a multiverse, as everyone seems to think these days, maybe it's just a cosmic mutation," Jenna said. "But that still doesn't explain why some are spared with each shift."

"We'll figure it out," Jeremy said, his hand caressing her forehead.

She kissed him, and they went back to being newlyweds.

Two months later, during the move, Jenna accidentally dropped a bag from her storage closet, and its contents spilled over the wild oak hardwood floor.

Jeremy kneeled down beside her, whistling. "I'll be damned," he said, picking out her blanket with knotted symbols. "I've never seen another one of these. My mum gave me mine when I was five, and I've no idea where she got it from. I thought it was unique."

Jenna stared, implications sinking in. "Our common factor?"

Together they researched the weird designs on the Internet. "Adinkra patterns," Jenna said. "Physicists use them in supersymmetric supergravity theories some believe the symbols may represent the fundamental codes that make up reality."

"Maybe that's what's protecting our memories," Jeremy said. "If we can learn what each symbol means, we might be able to rewrite the shops out of our reality! And then -"

But he'd gone too far, said too much.

This time Jenna didn't remember.

ALVARO ZINOS-AMARO is co-author, with Robert Silverberg, of When The Blue Shift Comes. 